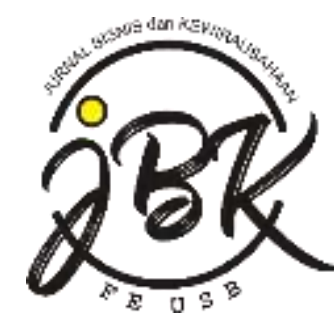

\title{
EVALUASI TINGKAT KEPUASAN PENGGUNA E-PATIENT (STUDI EMPIRIS PADA RSUD Dr. MOEWARDI SURAKARTA)
}

\author{
Andri Eko Saputro ${ }^{1}$ \\ Fakultas IImu Kesehatan, Universitas Setia Budi \\ (andrieko384@gmail.com@gmail.com) \\ Didik Setyawan ${ }^{2}$ \\ Fakultas Ekonomi, Universitas Setia Budi \\ (didiksetyawan1977@gmail.com) \\ Finisha Mahaestri Noor ${ }^{3}$ \\ Fakultas Ekonomi, Universitas Setia Budi \\ (finisha_noor@yahoo.com) \\ Sugiyarmasto ${ }^{4}$ \\ Fakultas Ekonomi, Universitas Setia Budi \\ (syarmasto@gmail.com)
}

\begin{abstract}
This study aims to test the satisfaction of using information systems formed from the patient's satisfaction with the quality of the service that is affected by the quality of the system and the perceived quality of information society in Solo while using e-patient applications. This study Thus confirm the research came back with a different object. Sampling technique was purposive sampling with the population of the community in the solo using the E-Patient application as much as 130 respondents. Testing the measuring instrument tested using the SPSS version 21 and hypothesis testing is done using Structural Equation Models (SEM) use the AMOS program. The results of this study indicate that patient satisfaction of using the $E$-Patient application significantly that from the quality of service. Quality system and quality of information on quality of service also showed significant effects. These results give Satisfaction to form meaning that patients in the use of the application E-Patient through the quality of service is affected by the quality of the system and the quality of the information.
\end{abstract}

Keyword: satisfaction of E-Patient, quality service, quality systems and quality of service.

\section{PENDAHULUAN}

Fenomena aplikasi pasien elektronik (e-patient) sebagai aplikasi layanan terhadap pasien dalam mempermudah pasien menarik untuk diteliti. Kemudahan tersebut berupa pendaftaran online, pemesanan resep obat, boking tempat, dan transaksi yang tersedia secara online sehingga dapat dilakukan kapanpun dan dimanapun. Penerapan e-patient menjadi suatu hal yang sangat penting untuk mengintergrasikan seluruh informasi yang dihasilkan dalam proses pelayanan. Hal ini dikarenakan dengan adanya e-patient dapat mendukung proses pelayanan kesehatan, proses dan operasi pelayanan kesehatan, 
pengambilan keputusan, manajemen, dan dapat sebagai keunggulan kompetitif (Hariana et al., 2013). Pelayanan kepada pasien dengan aplikasi e-patient ini diharapkan dapat meningkatkan kepuasan pasien terhadap layanan yang diberikan rumah sakit.

Evaluasi aplikasi e-patient yang merupakan sofware yang terintegrasi dengan Sistem Informasi Manajemen Rumah Sakit (SIMRS) masih menjadi kajian penting. Hal ini dikarenakan e-patient sebagai data pasien yang terintergrasi dengan SIMRS yang berperan dalam memproses dan mengintegrasikan seluruh proses alur kerja layanan rumah sakit dalam bentuk koordinasi jaringan (Helia et al., 2018). Penggunaan e-patient mempunyai peran penting dalam membantu proses pelayanan yang lebih efisien, sehingga dapat meningkatkan kepuasan dari pasien (Ahmadi et al., 2015). Peneliti terdahulu pada berbagai negara juga masih ditemukan perbedaan hasil hubungan antara kualitas layanan terhadap kepuasan dari aplikasi yang terdapat pada sistem informasi kesehatan (Ahmadi et al., 2015; Helia et al., 2018; Xie et al., 2018). Maka studi ini membangun model alternatif dalam menjelaskan pemanfaatan layanan kesehatan penggunaan aplikasi e-patient.

Studi ini dalam membentuk kepuasaan pasien terhadap layanan aplikasi e-patient dipengaruhi oleh kualitas layanan sebagai variabel mediasi yang dibentuk dari kualitas sistem dan kualitas informasi (Gorla et al.,
2010; Cohen et al., 2016; Kuo et al., 2018). Variabel-variabel tersebut adalah variabel kuat yang secara teoritis dalam membentuk kepuasan pasien terhadap e-patient. Kualitas layanan menjadi faktor yang penting dalam menentukan kepuasan pasien terhadap sistem informasi kesehatan (Kuo et al., 2018). Variabel lain yang menjadi pendorong kepuasan pasien terhadap epatient adalah kualitas sistem (Gorla et al, 2010). Hal ini dikarenakan kualitas sistem pada suatu rumah sakit yang berkualitas tinggi dan mempunyai sistem yang canggih dapat menyajikan kualitas layanan yang bermanfaat. Variabel lain yang dapat menjadi faktor pendorong kepuasan pasien terhadap e-patient adalah kualitas informasi (Cohen et al., 2016). Informasi yang akurat dan sesuai dari sistem informasi kesehatan dapat mempermudah tenaga kerja kesehatan dalam memproses,mencatat, menyampaikan hasil pemeriksaan dengan baik. Keakuratan informasi inilah yang dapat meningkatkan kepuasan pasien terhadap epatient

\section{A. TELAAH LITERATUR \\ Kepuasan}

Kepuasan pelayanan adalah suatu harapan individu sebelum melakukan keputusan atas pilihan yang dilakukan terhadap hasil sesudah melakukan pilihan tersebut (Torkzadeh dan Doll, 1999). Penjelasan tersebut diperkuat oleh Kotler dan Gertner (2002) mendefinifikan Kepuasan pelanggan adalah tingkat 
$\begin{array}{llr}\text { perasaan seseorang selah } & \text { sesil yang }\end{array}$ dirasakan dengan harapannya. Berdasarkan penjelasan tersebut dapat disimpulkan bahwa kepuasan adalah suatu kondisi dimana terpenuhinya suatu harapan dari individu terhadap suatu suatu produk tertentu.

Studi terdahulu menunjukan adanya beragam variabel pembentuk kepuasan pasien terhadap sistem informasi kesehatan antara lain Kualitas layanan (Kuo et al., 2018), keandalan (Gorla et al., 2010), kenyamanan layanan (Kaura et al., 2015). Namun studi ini membentuk kepuasan pasien terhadap sistem informasi kesehatan yang dipengaruhi oleh kualitas layanan (Kuo et al., 2018)

\section{Kualitas Layanan}

Kualitas layanan dalam konsep $e$ patient difefinikan sesuatu harapan konsumen yang diberikan saat menggunakan aplikasi e-patient yang sesuai dengan keinginan atau fakta yang sesuai dengan yang diharapkan oleh penerima layanan tersebut. Penjelasan tersebut diperkuat oleh Goode et al. (2017) menyatakan bahwa kualitas layanan adalah pemberi atau penyedia layanan dalam sistem informasi dalam bentuk bentuk aplikasi untuk mempermudah para konsumen dalam melakukan pendaftaran. Berdasarkan penjelasan tersebut konsep kualitas layanan dalam konteks e-patient didefinisikan sebagai penyedia layanan yang memberikan kepuasan sesuai harapan dan keinginan konsumen dalam aplikasi $e$ patient.

Studi terdahulu menunjukkan adanya hubungan yang kuat antara kualitas layanan dari aplikasi terhadap kepuasan pasien (DeLone dan McLean, 2016). Kualitas layanan yang dipersepsikan tinggi dan sesuai dengan kebutuhan konsumen merupakan faktor yang penting untuk meningkatkan kepuasan konsumen (Lin, 2017). Pendapat yang sama juga di ungkapkan oleh Kuo et al. (2018) mengungkapkan bahwa kualitas pelayanan menjadi faktor yang penting dalam meningkatkan kepuasan pasien terhadap aplikasi e-patient. Penjelasan tersebut memberikan makna bahwa kualitas layanan dalam aplikasi dipersepsikan tinggi oleh pasien akan mempengaruhi tingkat kepuasan pasien terhadap aplikasi epatient. Maka hipotesis yang diajukan adalah.

$\mathrm{H}_{1}$ : tingginya kualitas layanan dari aplikasi yang dipersepsikan dapat meningkatkan kepuasan yang dirasakan individu terhadap aplikasi $e$ patient.

\section{Kualitas Sistem}

Kualitas sistem merupakan kumpulan prosedur yang terdokumentasi dan praktekpraktek standar untuk manajemen sistem yang bertujuan memenuhi kesesuaian terhadap harapan yang dibutuhkan dari suatu proses dan produk barang atau jasa (DeLone dan McLean, 2003). Penjelasan tersebut diperkuat oleh Sedera dan Gable 
(2004) yang mendefinisikan kualitas sistem adalah kualitas perangkat keras dan perangkat lunak dalam suatu sistem informasi yang mempunyai kemampuan canggih dalam menyediakan informasi terhadap kebutuhan penggunanya (Sedera dan Gable, 2004). Hal tersebut dapat dimanknai bahwa kualitas sistem adalah kualitas dari kombinasi hardware dan software dalam sebuah sistem informasi yang dapat mendukung kinerja dari aplikasi yang menyediakan informasi yang sesuai dengan kebutuhan penggunanya

Studi terdahulu mengungkapkan kualitas sistem mempunyai hubungan yang positif terkait kualitas layanan (Lin, 2017; Kuo et al., 2018). Studi yang dilakukan oleh Lin, (2017) mengatakan kualitas sistem yang menggunakan teknologi tinggi akan mempengaruhi kepuasan individu terhadap suatu sistem tersebut melalui peran kualitas pelayanan. Pendapat ini diperkuat oleh Kuo et al., (2018) yang mengungkapkan bahwa kualitas sistem dari SIMRS dapat meningkatkan kualitas layanan aplikasi $e$ patient pada pasien untuk meningkatkan kepuasan pasien. Berdasarkan hasil tersebut dapat dijelaskan bahwa kualitas sistem yang dipersepsikan tinggi akan meningkatkan kualitas layanan dalam membentuk kepuasan pasien terhadap epatient. Maka hipotesis yang diajukan sebagai berikut.

$\mathrm{H}_{2}$ : tingginya kualitas sistem yang dipersepsikan dapat meningkatkan kualitas layanan aplikasi e-patient.

\section{Kualitas Informasi}

Kualitas informasi dalam konteks aplikasi e-patient didefinisikan sebagai sejauh mana informasi yang disampaikan dapat memberi manfaat bagi penggunanya (Swanson, 1997). Penjelasan tersebut diperkuat oleh Kuo et al., (2018) menyatakan bahwa kualitas informasi dalam konteks e-patient didefinisikan sebagai tingkat kesesuaian informasi dari sebuah sistem informasi yang bermanfaat dan berguna untuk melayani kebutuhan pasien. Berdasarkan penjelasan tersebut konsep kualitas informasi dalam konteks e-patient didefinisikan sebagai tingkat kesesuaian informasi dari suatu sistem informasi yang menyajikan informasi bermanfaat dan berguna untuk melayani kebutuhan pasien.

Studi terdahulu menjelaskan kualitas informasi berdampak positif terhadap kualitas layanan yang tersedia dalam aplikasi terhadap kepuasan pasien (Kaura et al., 2015; Cohen et al., 2016; Kuo et al., 2018). Studi yang dilakukan oleh Kaura et al. (2015) menyatakan Karyawan akan melayani pasien dengan baik jika kualitas informasi yang tersedia dalam sistem informasi kesehatan dapat mempermudah proses pelayanan kesehatan terhadap pasien. hal yang sama diungkapkan oleh Cohen et al. (2016) menunjukkan bahwa kualitas informasi sistem informasi kesehatan berpengaruh positif terhadap kualitas layanan untuk membentuk kepuasan pasien terhadap aplikasi pendaftaran online. Hasil yang sama juga 
diungkapkan oleh Kuo et al., (2018) yang menjelaskan bahwa individu akan merasa puas dengan kualitas informasi dari sistem informasi kesehatan apabila pasien merasa mudah dalam mendapatkan informasi tentang hasil pemeriksaan kesehatannya melalui peran kualitas layanan yang tersedia dalam aplikasi pendaftaran online. Berdasarkan penjelasan tersebut dapat diartikan bahwa tingginya kualitas informasi dalam SIMRS akan meningkatkan kualitas layanan yang tersedia dalam aplikasi epatient untuk membentuk kepuasan pasien terhadap penerapan aplikasi e-patient. Maka hipotesis yang diajukan sebagai berikut:

$\mathrm{H}_{3}$ : tingginya kualitas informasi yang dipersepsikan dapat meningkatkan kualitas layanan dalam penerapan aplikasi e-patient.

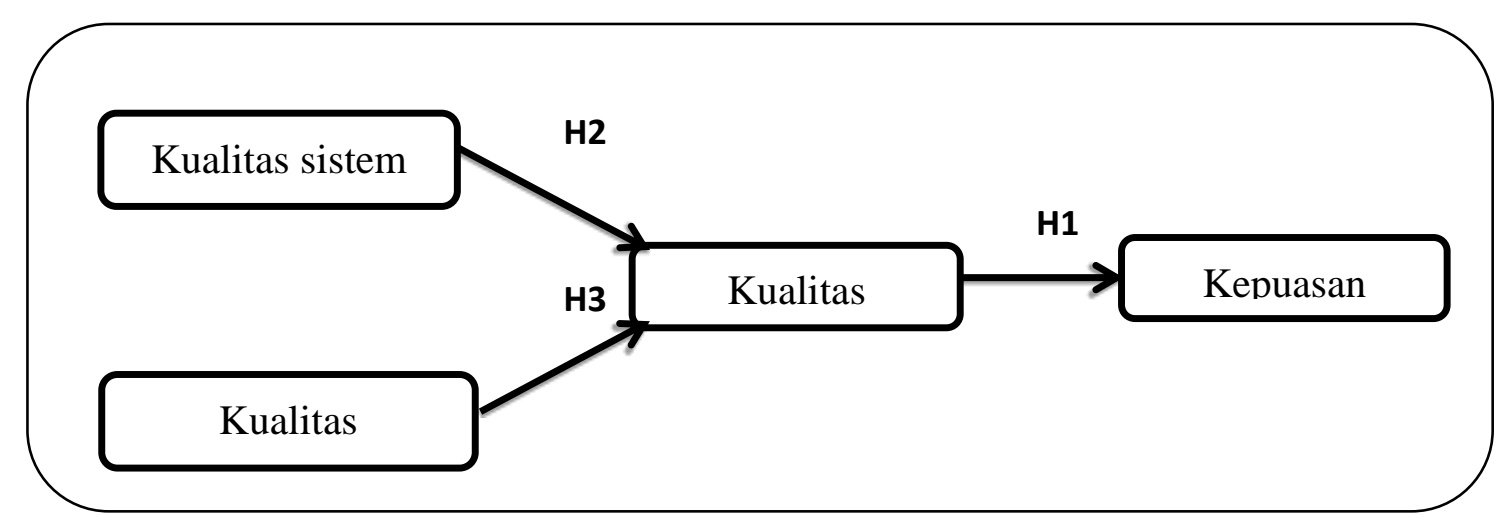

Gambar 1. Model Penelitian

\section{B. METODE PENELITIAN}

Jenis penelitian yang digunakan adalah penelitian causal. Jenis data pada penelitian ini adalah data cross-section. Obyek dalam penelitian ini sistem informasi di RSUD dr. Moewardi Surakarta dengan pasien yang menggunakan aplikasi e-patient berjumlah 130 responden. Teknik penyampelan yang digunakan adalah non probability sampling. Pengujian alat ukur dalam penelitian ini menggunakan uji validitas dan uji reliabilitas dengan program SPSS. Uji hipotesis dalam penelitian ini dilakukan dengan analisis Structural Equation Model (SEM) dengan program AMOS 


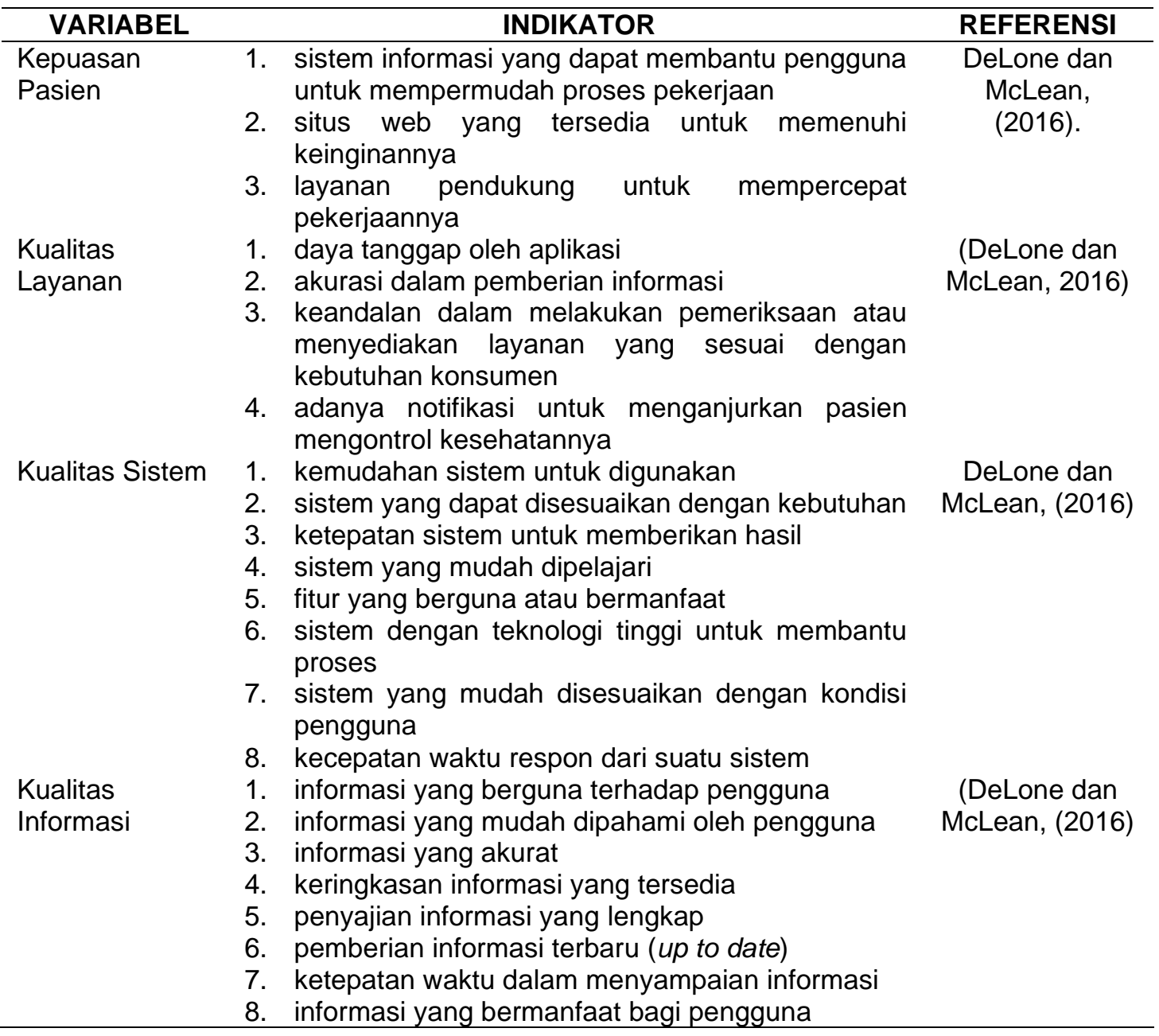

Tabel 1. Indikator Pengukuran Variabel

\section{HASIL ANALISIS}

Hasil pengujian alat ukur pada 23 item kuisioner seluruh item dapat digunakan untuk pengujian hipotesis dikarenakan nilai loading factor lebih besar dari 0,55 serta tidak mempunyai nilai ganda (cross loading) dalam kolom-kolom yang ada, maka item koesioner tersebut dikatakan valid. Hasil uji validitas disajikan dalam tabel 2. Pengujian realiabilitas dengan menggunakan metode Cronbach Alpha (a).Reliabilitas butir kuesioner diketahui dan koefisien alpha ( $\alpha$ ). Berdasarkan hasil pengujian mempunyai nilai reliabilitas lebih besar dari 0,6 sehingga dapat disimpulkan semua item kuesioner reliabel digunakan untuk mengambil data. 


\begin{tabular}{cccc}
\hline $\begin{array}{c}\text { Butir } \\
\text { kuesioner }\end{array}$ & $\begin{array}{c}\text { Loading factor } \\
\text { Minimal= } \mathbf{0 , 5 5}\end{array}$ & $\begin{array}{c}\text { Nilai Cronbach Alpha } \\
\text { Minimal= } \mathbf{0 , 6 0}\end{array}$ & Keterangan \\
\hline K1 & 0,828 & 0,812 & Valid dan reliabel \\
K2 & 0,840 & & Valid dan reliabel \\
K3 & 0,881 & & Valid dan reliabel \\
KL1 & 0,896 & 0,905 & Valid dan reliabel \\
KL2 & 0,885 & & Valid dan reliabel \\
KL3 & 0,924 & & Valid dan reliabel \\
KL4 & 0,822 & & Valid dan reliabel \\
& & \\
KS1 & 0,906 & 0,955 & Valid dan reliabel \\
KS2 & 0,846 & & Valid dan reliabel \\
KS3 & 0,910 & & Valid dan reliabel \\
KS4 & 0,867 & & Valid dan reliabel \\
KS5 & 0,817 & & Valid dan reliabel \\
KS6 & 0,834 & & Valid dan reliabel \\
KS7 & 0,890 & & Valid dan reliabel \\
KS8 & 0,897 & & Valid dan reliabel \\
& & & Valid dan reliabel \\
KI1 & 0,835 & 0,938 & Valid dan reliabel \\
KI2 & 0,818 & & Valid dan reliabel \\
KI3 & 0,854 & & Valid dan reliabel \\
KI4 & 0,834 & Valid dan reliabel \\
KI5 & 0,796 & Valid dan reliabel \\
KI6 & 0,826 & Valid dan reliabel \\
KI7 & 0,828 & Valid dan reliabel \\
KI8 & 0,879 & &
\end{tabular}

Tabel 2. Hasil Uji Validitas dan Reliabilitas Koesioner

\begin{tabular}{|c|c|c|c|c|c|c|}
\hline Hipotesis & $\begin{array}{c}\text { Koefisien jalur } \\
\text { (Standardized } \\
\text { estimate) }\end{array}$ & C.R & $Z_{\text {tabel }}$ & $\mathbf{P}$ & $\begin{array}{c}\text { Hasil Uji } \\
\text { Hipotesis }\end{array}$ & Keterangan \\
\hline$\overline{\mathrm{KL}} \rightarrow \mathrm{K}$ & $-0,052$ & 2,248 & & 0,025 & Signifikan & $\mathrm{H}_{1}$ Terdukung \\
\hline $\mathrm{KI} \rightarrow \mathrm{KL}$ & 0,189 & 2,093 & 2,57 & 0,044 & Signifikan & $\mathrm{H}_{2}$ Terdukung \\
\hline $\mathrm{KS} \rightarrow \mathrm{KL}$ & 0,219 & 2,125 & & 0,039 & Signifikan & $\mathrm{H}_{3}$ Terdukung \\
\hline
\end{tabular}

Keterangan : Signifikan pada $\alpha=0,01$

Berdasarkan dari pengolahan data

Tabel 3. Hasil Uji Hipotesis

Berdasarkan dari pengolahan data diketahui bahwa $\mathrm{H}_{1}, \mathrm{H}_{2}$, dan $\mathrm{H}_{3}$ terdukung, dimana nilai critical ratio (c.r) lebih besardari nilai Ztabel. Hasil pengujian menggunakan analisis SEM dengan aplikasi AMOS menghasilkan model yang terlihat dalam Gambar 2 sebagai berikut. 


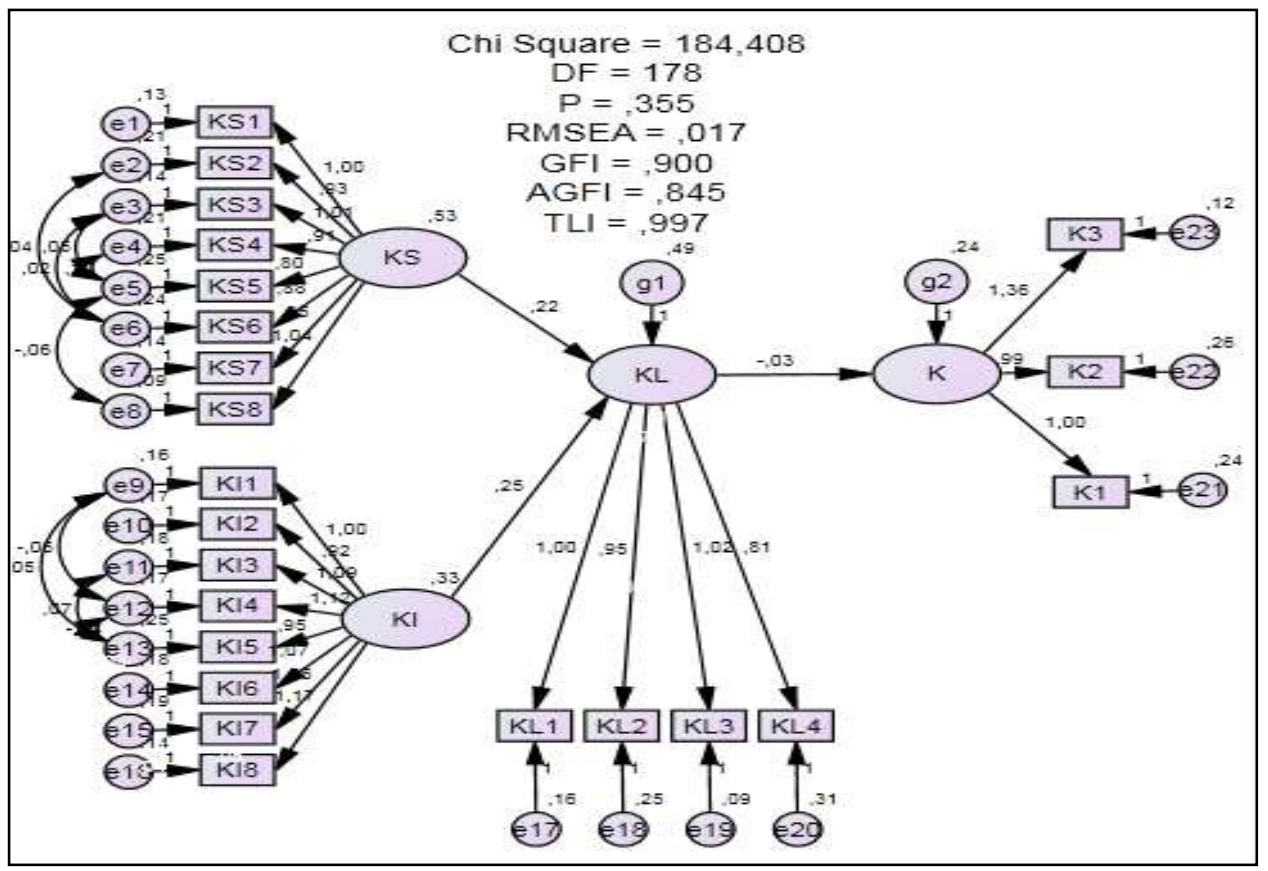

Gambar 2. Hasil Pengujian Model

\section{DISKUSI}

Model yang dibangun didasarkan variasi faktor-faktor pembentuk kepuasan yang terkonfirmasi dari studi sebelumnya. Hasil pengujian semua hipotesis terdukung. Hasil uji hipotesis 1 pada penelitian ini menjelaskan bahwa kualitas layanan berpengaruh signifikan terhadap terhadap kepuasan. Hal ini ditunjukan dengan adanya nilai probabilitas $(p)$ yang lebih kecil dari 0,05 yang dapat disimpulkan bahwa hipotesis terdukung. Hasil yang sama diungkapkan oleh DeLone dan McLean (2016) yang menyatakan adanya hubungan yang kuat antara kualitas layanan dari aplikasi e-patient terhadap kepuasan yang dikarenakan dengan adanya aplikasi e-patient dapat mempercepat waktu pendaftaran pasien. Hal ini juga diungkapkan oleh Lin (2017) yang menunjukan adanya konsistensi hasil pengaruh kualitas layanan terhadap kepuasan dikarenakan adanya kesesuaian kebutuhan konsumen terhadap keinginan konsumen sehingga dapat menigkatkan kepuasan konsumen. Pendapat lain juga dijelaskan oleh Kuo et al. (2018) yang menyebutkan kualitas layanan menjadi faktor yang penting dalam meningkatkan kepuasan pasien terhadap aplikasi e-patient. Berbagai penjelasan tersebut dapat dimaknai bahwa tingginya kualitas layanan dapat meningkatkan kepuasan konsumen terhadap aplikasi e-patient.

Hasil uji hipotesis 2 pada studi ini menunjukan bahwa adanya pengaruh signifikan antara kualitas sistem terhadap kualitas layanan. Hal ini ditunjukan dengan adanya nilai probabilitas ( $p$ ) yang lebih kecil dari 0,05. Hasil tersebut dapat disimpulkan bahwa hipotesis terdukung. Studi ini sesuai 
dengan yang dilakukan DeLone dan McLean (2016) yang menguangkapkan bahwa kualitas sistem mempunyai hubungan yang positif terkait kualitas layanan yang dipengaruhi oleh penggunaan sistem yang menggunakan teknologi tinggi sehingga dapat meningkatkan kualitas layanan dari aplikasi yang digunakan. Hal yang sama diungkapkan oleh Kuo et al. (2018) yang menunjukan bahwa kualitas sistem dari SIMRS dapat meningkatkan kualitas layanan aplikasi e-patient terhadap penggunaan pasien sehingga dapat menigkatkan kepuasan pasien. Hasil tersebut memberikan arti tingginya kualitas sistem dari suatu sistem dapat mempengaruhi kualitas layanan yang mampu meningkatkan kepuasan masyarakat untuk menggunakan aplikasi $e$ patient.

Hasil studi ini menunjukan adanya pengaruh signifikan antara kemudahan persepsian terhadap kualitas layanan. Hal ini ditunjukan dengan adanya nilai probabilitas (p) yang lebih kecil dari 0,05. Hasil tersebut dapat disimpulkan bahwa hipotesis terdukung. Studi ini sesuai dengan studi terdahulu yang dilakukan Kaura et al. (2015) yang mengungkapkan bahwa kualitas informasi dari suatu sistem informasi yang dapat mempermudah proses pelayanan pasien dapat meningkatkan kualitas layanan terhadapa pasien. Hal yang sama diungkapkan Cohen et al. (2016) kualitas informasi sistem informasi kesehatan berpengaruh positif terhadap kualitas layanan untuk membentuk kepuasan terhadap pasien. Kondisi ini dikarenakan kualitas informasi yang disajikan dari sistem informasi tersebut akan mempermudah pelayanan pasien sehingga pasien akan merasa puas dengan layanan yang tersedia tersebut. Pendapat ini dikuatkan oleh Kuo et al. (2018) yang mengungkapkan bahwa individu akan merasa puas dengan kualitas informasi dari sistem informasi kesehatan tentang hasil pemerikasaan kesehatanya melalui peran kualitas layanan yang tersedia dalam aplikasi pendaftaran online. Berbagai penjelasan tersebut dapat dimaknai bahwa tingginya kualitas informasi dalam SIMRS akan meningkatkan kualitas layanan yang tersedia dalam aplikasi e-patient untuk membentuk kepuasan pasien terhadap penerapan aplikasi e-patient.

\section{E. KESIMPULAN}

Berdasarkan analisis SEM menunjukan bahwa semua hipotesis terdukung. Hasil ini memberikan makna bahwa untuk membentuk kepuasan dalam penggunaan aplikasi e-patient dibentuk melalui kualitas layanan yang dipengaruhi oleh kualitas sistem dan kualitas informasi dari aplikasi e-patient. Pengguna aplikasi epatient akan mempersepsikan bahwa kualitas layanan dari aplikasi e-patient yang mempermudah keinginan pasien. Kualitas layanan dari aplikasi e-patient mempunyai peningkatan apabila sistemnya mempunyai kualitas yang baik dan memberikan informasi yang berkualitas dalam membentuk kepuasan pasien dalam menggunakan aplikasi e-patient. 


\section{REFERENSI}

Ahmadi, H., Nilashi, M., \& Ibrahim, O. (2015). Organizational Decision to Adopt Hospital Information System: An Empirical Investigation in The Case of Malaysian Public Hospitals. International Journal of Medical Informatics, Vol 84. No. 3, pp 166-188.

Banker, R. D., Robert J, K., \& Morey, R. C. (1990). Measuring Gains in Operational Efficiency from Information Technology: A Study of the Positran Deployment at Hardee's Inc. Journal of Management Information Systems, Vol 7. No. 2, pp 29-54.

Cohen, J. F., Coleman, E., \& Kangethe, M. J. (2016). An Importance-Performance Analysis of Hospital Information System Attributes: A Nurses' Perspective. International Journal of Medical Informatics, Vol 86, pp 82-90.

DeLone, W. H., \& McLean, E. R. (2003). The DeLone and McLean Model of Information System Success. Journal of Management Information Systems, Vol 19. No. 4, pp 9-30.

DeLone, W. H., \& McLean, E. R. (2016). Information Systems Success Measurement. Foundations and Trends in Information Systems, Vol 2. No 1, pp 1-116

G. Torkzadeh and W. J. Doll. (1999). The Development of A Tool For Measuring The Perceived Impact of Information Technology on Work. Omega, Vol 27. No. 3, pp 327- 339
Goode, S., Hoehle, H., Vankatesh, V., dan Brown, S. A., 2017. User Compensation As A Data Breach Recovery Action: An Investigation of The Sony PlayStation Network Breach. Mis Quarterly: Research Article, Vol 41. No. 3, pp 703727.

Gorla, N., Somers, T. M., \& Wong, B. (2010). Organizational Impact of System Quality, Information Quality, and Service Quality. Journal of Strategic Information Systems, Vol 19. No. 3, pp 207-228.

Hariana, E., Yoki Sanjaya, G., Ristya Rahmanti, A., Murtiningsih, B., \& Nugroho, E. (2013). Penggunaan Sistem Informasi Manajemen Rumah Sakit (SIMRS) di DIY. Seminar Nasional Sistem Informasi Indonesia, pp428-434 Eds Des.

Helia, V. N., Asri, V. I., Kusrini, E., \& Miranda, S. (2018). Modified Technology Acceptance Model for Hospital Information System Evaluation - A Case Study. MATEC Web of Conferences, Vol 154, pp 1-5.

Hu, H. J. P., Brown S. A., Thong, J. Y. L., Chan F. K. Y., dan Tam, Y. K., 2009. Determinants of Service Quality and Continuance Intention of Online Services: The Case of eTax. Journal of the American Society for Information Science and Technology, Vol 60, No. 2 pp 292-306.

Kaura, V., Durga P., C.S. \& Sharma, S. (2015). Service Quality, Service 
Convenience, Price and Fairness, Customer Loyalty, and The Mediating Role of Customer Satisfaction, International Journal of Bank Marketing, Vol. 33 No. 4, pp. 404-422.

Kotler, P., \& Gertner, D. (2002). Country As Brand, Product, and Beyond: A Place Marketing and Brand Management Perspective. Journal of Brand Management, Vol 9. No. 4, pp 249-261. Kuo, K. M., Liu, C. F., Talley, P. C., \& Pan, S. Y. (2018). Strategic Improvement for Quality and Satisfaction of Hospital Information Systems. Journal of Healthcare Engineering, Vol 1, pp 114.

Liu, D., dan Guo, X., 2018. Exploring Gender Differences in Acceptance of Mobile Computing Devices Among College Students. Springer-Verlag Berlin Heidelberg, Vol 15, No. 1, pp 197-223.

Lin, H. (2017). Nurses' Satisfaction With Using Nursing Information Systems From Technology Acceptance Model and Information Systems Success Model Perspectives: A Reductionist Approach, Computer Informatics Nursing, Vol. 35, Iss. 2, pp. 91-99

Meesala, A., \& Paul, J. (2016). Service quality, Consumer Satisfaction and Loyalty in Hospital: Thinking for The Future. Journal of Retailing and Consumer Services, Vol 1, pp 1-9.

Oliver, R. L. (1997). Satisfaction: A Behavioral Perspective on the
Consumer. New York: McGraw-Hill Irwin Vol 41, No. 3, pp. 703-727

Ozer, A., Argan, T. M., dan Argan, M. (2013). The Effect of Mobile Service Quality Dimensions on Customer Satisfaction. Procedia - Social and Behavioral Sciences, pp 428-438.

Parasuraman, A., Zeithaml, V. A., \& Berry, L. L. (1994). Reassessment of Expectations as a Comparison Standard in Measuring Service Quality: Implications for Further Research. Journal of Marketing, Vol 58. No. 1, pp 111-124.

Sedera, D., \& Gable, G. (2004). A Factor and Structural Equation Analysis of The Enterprise Systems Success Measurement Model. Proceedings of the Twenty-Fifth Americas International Conference on Information Systems, Washington, DC, 12-15 December, 2004., pp 449-464.

Swanson, B. (1997). Maintaining IS quality. Information and Software Technology Vol 39, pp 845-850

Xie, C., Yang, P., \& Yang, Y. (2018). Open Knowledge Accessing Method in loTBased Hospital Information System for Medical Record Enrichment. IEEE Access, Vol 6, pp 15202-15211. 